\title{
"ENTRE A ESTUPIDEZ E A LOUCURA": IMPLICAÇÕES ÉTICAS DO PRINCÍPIO DE IDENTIDADE E DO PRINCÍPIO DE RAZÃO (E ALGUMAS ALTERNATIVAS CONTEMPORÂNEAS)
}

\author{
[ "BETWEEN STUPIDITY AND MADNESS": INVESTIGATION ON THE ETHICAL IMPLICATIONS OF \\ THE PRINCIPLE OF IDENTITY AND OF THE PRINCIPLE OF REASON (WITH SOME CONTEMPORARY \\ ALTERNATIVES ]
}

Diogo Barros Bogéa * Universidade Estadual do Rio de Janeiro, Brasil

\begin{abstract}
RESUMO: Investigação sobre as implicações éticas do princípio de identidade e do princípio de razão. O princípio lógico de identidade $(\mathrm{A}=\mathrm{A})$, juntamente com o princípio de nãocontradição e o princípio do terceiro excluído constitui a base da lógica ocidental. No entanto, seu domínio não se restringe à lógica. Assim como o domínio do princípio de razão não se restringe à epistemologia e à ontologia. Com estes princípios se constrói toda uma visão de mundo com graves implicações éticas. Tentaremos ao final apontar alternativas contemporâneas a esses princípios alternativas que tragam consigo implicações éticas diferentes.
\end{abstract}

PalaVras-chave: Identidade; razão; ética
ABSTRACT: Abstract: Investigation on the ethical implications of the principle of identity and of the principle of reason. The logical principle of identity $(\mathrm{A}=\mathrm{A})$, along with the principle of non-contradiction and the principle of the third middle costitute the basis of ocidental logic. However, its dominance is not restricted to logic. As the dominance of the principle of reason is not restricted to epistemology and ontology. This principles constitute a whole worldvew with serious ethical implications. We'll try, at the end of the article, to indicate contemporary alternatives to this principles - alternatives which bring with themselves different ethical implications..

KEYWORDS: Identity; reason; ethics

\section{OS DOIS PRINCÍPIOS BÁSICOS DA RAZÃO OCIDENTAL} A metafísica ocidental está fundada sobre dois princípios básicos: o princípio

$\mathrm{O}$ princípio de identidade, junto com o princípio de não-contradição e $\mathrm{o}$ princípio do terceiro excluído, constitui a base da lógica ocidental. No entanto, a vigência desses três princípios não se limita à "lógica", eles são ao mesmo tempo produto e produtores de uma determinada ontologia (uma teoria do ser, uma maneira de conceber o ser das coisas, uma maneira perguntar e responder "o que são" as coisas) e de uma determinada epistemologia (uma maneira específica de perceber, definir, classificar e explicar o que são as coisas e como as coisas funcionam). Princípios lógicos carregam consigo - fundamentam e são fundamentados, legitimam e são legitimados, são já implicações, mas também produzem graves implicações onto-

* Professor de Filosofia na Faculdade de Educação da Universidade Estadual do Rio de Janeiro. Doutor e Mestre em Filosofia pela Pontifícia Universidade Católica do Rio de Janeiro. m@ilto: diogobogeaa@hotmail.com 
epistemológicas.

O princípio de identidade, consiste na pressuposição, na postulação e na afirmação de que um ente (algo que é), é idêntico a si mesmo, o que se traduz na fórmula $\mathrm{A}=\mathrm{A}$. Isto significa apenas que um dado objeto, pessoa, conceito, valor ou instituição são idênticos a si próprios, isto é, em termos muito simples, a mesa é mesa, o computador é o computador, eu sou eu, você é você, Deus é Deus, o Brasil é o Brasil, a Justiça é a Justiça, a Ciência é a Ciência. O princípio de identidade se desdobra em dois outros que lhe são complementares e sem os quais, portanto, resta incompleto. Se temos o princípio de identidade, temos então também o princípio de não-contradição, que consiste na negação da possibilidade de que um ente seja diferente de si mesmo, o que se traduz pela fórmula $\mathrm{A}$ é diferente de não-A. Isso também é muito simples de compreender e significa apenas que um dado objeto, pessoa, conceito, valor ou instituição, sendo idênticos a si próprios, não são qualquer outra coisa senão aquilo mesmo que são. Ou seja, mais uma vez em termos muito simples: se uma mesa é uma mesa, ela não é também um computador, nem é também uma pessoa, nem é também um Deus, nem é também um valor ou uma instituição. Se eu sou eu, não sou também você, nem sou também um edifício, nem sou também um livro... Por fim, estes dois princípios básicos levam a um terceiro, que, apenas por coincidência, se chama princípio do "terceiro excluído". O princípio do terceiro excluído decorre dos dois anteriores e tem por função garantir que eles sejam absolutamente válidos. Ele consiste apenas no seguinte: dado que $\mathrm{A}=\mathrm{A}$ e $\mathrm{A}$ é diferente de $\mathrm{B}$, qualquer "terceira" opção está automaticamente "excluída". Logo, A não pode ser igual a B, nem pode ser diferente de si próprio. Isto, como já se supõe, quer apenas dizer que sendo um dado ente idêntico a si próprio e diferente de todo "outro", a afirmação de que um ente seja um outro, ou de que um ente seja e não seja ele mesmo é por princípio absurda, infundada e ilógica.

Curiosamente, Aristóteles não fornece nenhuma prova positiva do princípio de não-contradição. Ele utiliza uma prova pela negativa, através do chamado princípio "anhipotético". O princípio anhipotético consiste apenas no seguinte: dado um certo postulado (1), o seu contrário (2) não pode se produzir sem ao mesmo tempo reafirmálo. Aristóteles afirma ser assim com o princípio de não-contradição: mesmo que se queira contestá-lo, é necessário que se o faça através de uma construção frasal coerente em que os termos significam exatamente aquilo que significam, isto é, uma construção frasal em que os "As" sejam iguais aos "As" e diferentes dos "Bs" (ARISTÓTELES, 2002, IV, 3).

\section{IMPLICAÇõES DO PRINCÍPIO DE IDENTIDADE}

O princípio de identidade, nesses termos, parece algo da ordem de uma constatação completamente óbvia e banal, que apenas o espírito excêntrico e distorcido dos filósofos pode ter se preocupado em estabelecer como princípio. No entanto, suas implicações ontológicas são gravíssimas: tendemos a compreender os entes como "algo" "em si", isto é, idênticos a si mesmos, fechados sobre si mesmos, possuidores de uma essência única e própria e cercados por fronteiras rígidas que os diferenciam absolutamente dos outros. Nesse sentido, temos a forte tendência a considerar a "mesa" como objeto único existente por si mesmo para além de toda e qualquer relação. Tendemos a imaginar - ainda que nem sequer saibamos formular a coisa nesses termos - que um objeto é algo previamente dado em si e por si mesmo e que as relações que estabelece e as mudanças e transformações pelas quais passa são apenas "acidentais", não afetando o núcleo da sua "essência" própria. Tendemos também a conceber 
“objetos", "instituições", "pessoas", "valores", como entes muito bem delimitados por fronteiras rígidas e, portanto, como essencialmente diferentes uns dos outros, preservando sempre, não importa o tanto de relações acidentais que estabeleçam, algum nível de "pureza" essencial.

Constrangidos pela força invisível do princípio de identidade, costumamos realmente em geral conceber a "mesa" como "mesa", objeto já em princípio diferente de "mim", do "computador", dos "livros", das "paredes". Mas quando estamos tratando de mesas, livros e computadores, as consequências podem não ser tão graves. No entanto, as consequências ontológicas do princípio de identidade não param por aí. Tendemos a conceber pessoas como um "eu" único, com uma essência determinada, com atributos e propriedades também determinadas, e as julgamos com base em sua suposta "identidade". Julgamos que, com base nessa "identidade" uma pessoa deva se comportar de uma determinada maneira, mantendo uma constância lógica ao longo das situações. E nossa crença no princípio de identidade vai tão longe, que a cada vez que ele insiste em falhar e o comportamento humano se mostra escancaradamente ilógico, contraditório e absurdo, nos surpreendemos com a mesma intensidade e dizemos "aquele não era você/ nem parecia você/ estava "possuído"", ou coisa to tipo. E nossa crença na firmeza infalível do princípio de identidade não se aplica apenas às "outras" pessoas, mas também a nós mesmos. Acreditamos na pureza da nossa "autoidentidade", o que costumamos corriqueiramente reafirmar pelo uso repetido da palavra "eu". "Eu sou", “eu sei”, “eu quero", “eu vou", "eu posso", reintroduzem sem cessar a certeza inquestionada e inquestionável de que antes de qualquer "verbo" ou "predicado", lá estava, firme e forte, em sua pureza essencial, a presença autoidêntica do "sujeito". E isto mesmo apesar desse nosso "eu", mais do que qualquer "outro", não cessar de nos dar demonstrações constantes da sua inconstância, incorrendo sem cessar em flagrantes inconsistências lógicas.

\section{BINARISMO E ÉTICA}

Mas o domínio do princípio de identidade não para ainda por aí. Ele atravessa e permeia também nossa axiologia (princípios de valoração) e nossa epistemologia (nossos saberes sobre as coisas). Afinal, se um ente é necessariamente idêntico a si mesmo (logo, diferente de todos os outros, sem qualquer possibilidade de uma terceira opção), ele só pode ser "verdadeiro" ou "falso", "justo" ou "injusto", "bom ou mau", só pode estar "certo" ou "errado", "presente" ou "ausente". Com isso, "verdade" e "falsidade", "justiça” e "injustiça", "bem" e "mal", "correção" e "erro", "presença" e "ausência" são também concebidos no registro do princípio de identidade, isto é, são concebidos como "algo" dado "em si" e "por si" mesmo, entes subsistentes bem definidos e demarcados por fronteiras rígidas - quiçá intransponíveis. Daí uma lógica fundada no princípio de identidade ser essencialmente "binária". Uma lógica do "ou, ou", opositiva e excludente que toma cada um dos seus termos como polos autoidênticos dados por si mesmos em sua pureza essencial, um diante do outro numa oposição irreconciliável. Afinal, se $\mathrm{A}=\mathrm{A}$, ou estamos falando de $\mathrm{A}$, ou de $\mathrm{B}$ "terceiros" excluídos.

Com isso, chegamos a uma grave implicação Ética do princípio (onto)lógico de identidade. Operando numa lógica necessariamente binária, opositiva e excludente, desenvolvemos uma forte tendência a tomar o "outro", o "diferente" como "oposto". Numa lógica identitária e, portanto, binária e excludente, não há qualquer possibilidade de conciliação com o "outro". O máximo que se pode aspirar é "tolerar", e a palavra 
"tolerar" não esconde - pelo contrário, reafirma - a negatividade do "outro", pois só se é obrigado a "tolerar" coisas ruins, porém suportáveis. As formas de lidar com um "outro" que não é concebido como apenas "diferente", mas como necessariamente "oposto", são sempre negativas e violentas: dominação, conversão, inferiorização, perseguição, exclusão, confinamento, exílio e extermínio - mais ou menos velados, mais ou menos agressivos, mais simbólicos ou mais carnais. E se essas palavras parecem demasiado cruéis e pesadas para se referirem a um ser racional, consciente, responsável, ético, moral... um breve passeio pelos livros de história ou pelos noticiários do dia nos mostra que elas são ainda brandas e insuficientes para dar conta da ferocidade humana.

\section{A NOÇÃo de "CAUSA"}

O princípio de identidade nos diz que as coisas são o que são, no entanto, nada tem a dizer sobre o porquê das coisas serem como são. Por que, pelo que, através de que, por que razão as coisas chegam a ser e são? Perguntar o porquê é perguntar as causas das coisas. Talvez ninguém mais, em nenhum outro tempo ou lugar, tenha levado tão longe a obsessão de investigar as causas das coisas quanto os gregos antigos. Sua obsessão se faz presente ainda hoje no desenfreado desenvolvimento tecnocientífico que a esta altura já alterou por completo a face do planeta. "Causa" em grego se diz "aition", que significa "dívida" e "comprometimento". Perguntar pelas causas de um ente, significa, portanto, perguntar a que se deve sua existência, com o que é que ele está comprometido (HEIDEGGER, 2012, pp.13-16).

Ao contrário do que acreditava Kant, é muito difícil imaginar que exista - e que tenha existido desde que o humano é humano - um "sujeito puro" do conhecimento, uma série de "formas" e "categorias" a priori a partir das quais o humano percebe e compreende o mundo. Para falar numa linguagem mais atual, é como se existe uma "programação mental" própria do humano: as "formas puras da intuição sensível": tempo e espaço, e as 12 categorias, dentre as quais figura a "causalidade". A partir dessa "programação" inicial, o humano "processaria" a realidade de uma determinada forma, ou seja, tudo sempre já nos aparece como algo situado no tempo, no espaço e no âmbito de certas categorias, como, por exemplo, a causalidade (KANT, 1974, pp. 40-71). A aposta de Nietzsche é muito mais plausível, quando, contra Kant, afirma que todas as "faculdades" do humano passaram por um longo e caótico processo de desenvolvimento, cuja maior parte se deu em nossa extensa pré-história. Todas as "faculdades cognitivas" do nosso "aparelho de conhecimento", como o raciocínio lógico, o raciocínio causal, o cálculo, a capacidade de fazer - e realizar - planos, tudo isso deve ter passado por um longo e sofrido processo de desenvolvimento. E um desenvolvimento que de forma alguma pode ser concebido como uma "evolução espiritual pura", mas que envolve o entrelaçamento de uma rede de circunstâncias de todos os tipos: fisiológicas, climáticas, materiais, sociais, culturais, econômicas etc.

Todos os filósofos têm em comum o defeito de partir do homem atual e acreditar que, analisando-o, alcançam seu objetivo. Involuntariamente imaginam "o homem" como uma aeterna veritas, como uma constante em todo o redemoinho, uma medida segura das coisas. Mas tudo o que o filósofo declara sobre o homem, no fundo, não passa de testemunho sobre o homem de um espaço de tempo bem limitado. Falta de sentido histórico é o defeito hereditário de todos os filósofos; inadvertidamente, muitos chegam a tomar a configuração mais recente do homem, tal como surgiu sob a pressão de certas religiões e 
mesmo de certos eventos políticos, como a forma fixa de que se deve partir. Não querem aprender que o homem veio a ser, e que mesmo a faculdade de cognição veio a ser; enquanto alguns deles querem inclusive que o mundo inteiro seja tecido e derivado dessa faculdade de cognição. - Mas tudo o que é essencial na evolução humana se realizou em tempos primitivos, antes desses quatro mil anos que conhecemos aproximadamente; nestes o homem já não deve ter se alterado muito. O filósofo, porém, vê "instintos" no homem atual e supõe que estejam entre os fatos inalteráveis do homem, e que possam então fornecer uma chave para a compreensão do mundo em geral: toda a teleologia se baseia no fato de se tratar o homem dos últimos quatro milênios como um ser eterno, para o qual se dirigem naturalmente todas as coisas do mundo, desde o seu início. Mas tudo veio a ser; não existem fatos eternos; assim como não existem verdades absolutas. Portanto, o filosofar histórico é doravante necessário, e com ele a virtude da modéstia. (NIETZSCHE, HH, § 2)

Isso se nota na própria noção grega de "causa", que remete a "dívida" e "comprometimento", noções que devem ter surgido em primeiro lugar no âmbito das trocas materiais tão necessárias à sobrevivência de qualquer comunidade humana ${ }^{1}$. Estar em dívida, até não muito tempo atrás - talvez até pouco antes da lógica capitalista fazer do endividamento o fundamento de todo um sistema sociocultural -, era estar inteiramente sob o domínio do credor, inteiramente comprometido com o credor, de maneira que, para o endividado, seu próprio ser se devia ao credor. Investigar as causas, portanto, significa de certa forma investigar a que se deve o ser de um ente.

\section{Logos}

O surgimento da Filosofia está diretamente ligado - meio como causa, meio como consequência - à ascensão do pensamento lógico. Pensamento lógico, nesse momento, nada tem a ver com uma disciplina específica chamada "lógica", que, por meio de complicadas fórmulas tenta compreender como funcionam certos aspectos da mente humana. É somente com Aristóteles e seu Organon que a lógica se torna uma espécie de disciplina específica. Organon significa "ferramenta" e pretende justamente fornecer uma "caixa de ferramentas" para compreender e "ajustar" o pensamento e o discurso. A palavra logos significa justamente um amálgama de "pensamento" e "discurso", "palavra". Não se trata, no entanto, de qualquer discurso, mas do discurso argumentativo que apresenta razões, apresenta as razões de ser daquilo de que fala e, o fazendo, apresenta suas próprias razões de ser. Logos, portanto, é o discurso que, fornecendo razões, fundamenta, e por esse mesmo movimento, se apresenta como discurso fundamentado.

O logos como discurso fundamentado é justamente aquele que se opõe, num primeiro momento, ao mito, o discurso da tradição, todo baseado nos caprichos e idiossincrasias de forças divinas, no âmbito do qual não existe questionamento, apenas se acredita ou não. Num momento posterior, já com Sócrates e Platão, o logos se opõe também à doxa, o discurso da da opinião, isto é, o discurso que se atém apenas às aparências e às paixões, sem se preocupar em investigar as verdadeiras razões do seu objeto. O pensamento lógico só faz sentido para os gregos, porque eles acreditam firmemente no kosmos, isto é, acreditam que o mundo é constituído por uma ordem intrínseca, que, por ser homóloga à ordem do discurso e do pensamento, pode ser investigada, dita, pensada, conhecida. Há uma compatibilidade intrínseca entre a ordem das coisas e a ordem do discurso que possibilita e legitima o falar e o pensar sobre as coisas. Há uma ordem de dívidas e comprometimentos através dos quais as coisas e o 
pensamento vem a ser.

Aristóteles nos diz que existem quatro causas: material, formal, final e eficiente (ARISTÓTELES, 2002, I, 3). No clássico exemplo da escultura de mármore, o mármore é a causa material, a matéria de que o ente é feito; o modelo, a ideia, o conceito é a causa formal, a forma que se apropria daquela matéria; enfeitar o templo agradando aos deuses é a causa final (a finalidade); e o escultor, aquele que produz, é a causa eficiente. Um ente deve sua existência a estas quatro causas que estão comprometidas entre si e com as quais ele, desde que vem a ser, está comprometido.

\section{O PrincíPIo de Razão Suficiente}

Mas toda essa longa digressão tinha o propósito de introduzir o segundo princípio (onto)lógico da razão ocidental. Ele se chama "Princípio de Razão Suficiente" e, com esta denominação, aparece apenas no início da modernidade, na formulação de Leibniz. O princípio de razão suficiente, tal como formulado por Leibniz, diz: "nenhum fato pode ser tomado como verdadeiro ou existente, nem algum enunciado como verídico, sem que haja uma razão suficiente para ser assim e não de outro modo" (LEIBNIZ, 1966, p. 158). Outra forma de enunciar, mais concisa, diz apenas: "Nada é sem razão" e o seu significado é autoevidente. Um dado evento "p1" é "razão suficiente" para que ocorra o evento "p2", que é "razão suficiente" para que ocorra o evento "p3" e assim por diante.

Embora o "princípio de razão" só tenha sido formulado na modernidade, sabemos que o raciocínio causal e a busca e a apresentação de razões não são estranhas ao espírito grego. Os filósofos pré-socráticos, nossos primeiros e talvez mais geniais pensadores, fizeram a experiência de uma espécie de aporia fundamental da causalidade. Trata-se do seguinte: para que as coisas interfiram umas nas outras, para que possam dar origem uma à outra, para que possam afetar umas às outras e ser afetadas de qualquer maneira umas pelas outras, é preciso que elas tenham algo em comum. Coisas que nada tivessem em comum não poderiam estabelecer qualquer tipo de relação, seriam absolutamente in-comun-icáveis. Mas as relações e afetações mútuas existem, então, é preciso que haja algo em comum entre todas as coisas existentes. Heráclito disse "é preciso seguir o que é-com" (HERÁCLITO, 2000, fr. 2), o que é comum. Diógenes de Apolônia chegou àquela que talvez seja a mais bela e precisa formulação desta compreensão fundamental:

todas as coisas são diferenciações de uma única coisa e são a mesma coisa. E isto é evidente. Porque se as coisas que são agora neste mundo - terra, água, ar e fogo e as outras coisas que se manifestam nesse mundo -, se alguma destas coisas fosse diferente de qualquer outra, diferente em sua natureza própria, e se não permanecesse a mesma coisa em suas muitas mudanças e diferenciações, então não poderiam as coisas, de nenhuma maneira, misturar-se umas às outras, nem fazer bem ou mal umas às outras, nem a planta poderia brotar da terra, nem um animal ou qualquer outra coisa vir à existência, se todas as coisas não fossem compostas de modo a serem as mesmas. Todas as coisas nascem, através de diferenciações, de uma mesma coisa, ora em uma forma, ora em outra, retornando sempre à mesma coisa. (ap. BORNHEIM, 1998, p. 95)

Daí a busca pré-socrática pelo "princípio comum" (arché) de todos os entes.

No entanto, apesar da necessidade de que haja um "princípio comum", os entes são evidentemente diferentes. Então, questão das questões: como pensar a unidade na multiplicidade? A mesmidade na diversidade? A água, o fogo, o ar inteligente, o apeiron 
(o indeterminado ilimitado), os átomos, assumem esse lugar de um mesmo princípio comum cujas transformações dão origem à diversidade múltipla dos entes existentes. Trata-se em cada caso de um princípio originário imanente, isto é, um princípio que permanece entranhado nas coisas que origina. Não pode se tratar de um princípio que repouse soberano "para além" das coisas, pois se assim fosse, ele não teria nenhum poder de afetação sobre as coisas. É preciso que se trate de um princípio dinâmico capaz tanto de transformação quanto de permanência, um princípio que permanece em cada transformação e que se transforma mesmo na permanência. Aporia da causalidade, aporia da Existência: como pensar a mais radical transformação em meio à mais intransigente permanência? Como pensar a mais plena unidade em meio à mais variada diversificação?

\section{A Filosofia Na POLIS democrática}

Quando a Filosofia se estabelece em Atenas, fazendo da cidade sua capital, essas questões se desdobram de uma outra maneira, ganham um novo aspecto e um outro desenvolvimento. Atenas fundou uma experiência política sem precedentes na história humana. Uma experiência que, na verdade, deu origem à própria palavra "política": a experiência democrática. A democracia ateniense experimentou uma forma inédita de exercício do poder. Ao invés da espada, do sangue, do prestígio, da linhagem e da força bruta (o uso efetivo ou a ameaça permanente do uso efetivo da força bruta), o poder se exercia através da palavra, do logos, no discurso argumentativo dos cidadãos reunidos em assembleia ${ }^{2}$. As grandes questões relativas à administração da polis eram decididas nas assembleias, nos debates entre discursos divergentes que deveriam se mostrar capazes de convencer o maior número de cidadãos.

Nesse contexto, surgem os sofistas, os grandes mestres do logos, que ensinavam aos cidadãos a arte do discurso bem fundamentado. A tradição nos deixou dos sofistas a imagem de "mercenários" "descompromissados com a verdade", que "cobravam caro por seus ensinamentos". Ora, isso se deve apenas ao seguinte: a história dos sofistas foi escrita por seu maior rival, Platão. Que seria de cada um de nós se a escrita da nossa história de vida ficasse nas mãos dos nossos maiores desafetos? Os sofistas cobravam por seus ensinamentos porque eram bons professores - os primeiros professores propriamente ditos da história. Eram bons professores na arte mais decisiva para a vida humana: a arte da palavra - numa sociedade em que a palavra é poder. E por que um bom professor deveria trabalhar de graça?

Por outro lado, os sofistas são "descompromissados com a verdade" porque fazem uma experiência singular do logos, uma experiência que só com muita dificuldade reaparece no pensamento ocidental em momentos pontuais e locais. Trata-se da experiência de um logos vivo, aberto, em processo permanente de estabilização, mas sempre necessariamente instável. Os sofistas arriscam uma experiência do logos que insiste na boa fundamentação do discurso, mas recusa decididamente a fundamentação absoluta. Não há fundamentação absoluta, não há Verdade com V maiúsculo, não há deuses ou critérios externos ao jogo aos quais possamos recorrer. As verdades se fazem no discurso, os critérios nascem e morrem no discurso. Nesse sentido, há uma frase bastante emblemática de Protágoras: "Sobre os deuses, não tenho possibilidade de saber se existem ou não, nem qual é a sua forma. Muitas são as razões que me impedem tal conhecimento: a obscuridade da questão e a brevidade da vida" (PROTÁGORAS, 1982, p. 257)

Uma tal experiência aberta, viva, dinâmica e caótica do logos traz riscos. Os 
riscos e vícios da democracia que Platão não cessará de apontar - e que ainda hoje conhecemos muito bem na prática: na ausência de um critério absoluto, há o risco das piores propostas, sendo apresentadas pelos melhores discursos, saírem vencedoras; há o risco de um pequeno grupo fazer valer seus interesses particulares em detrimento do bem comum; há o risco de que as paixões e aparências predominem; há o risco de que uns poucos ganhem prestígio e autoridade suficientes para fazer valer repetidamente seus interesses, exercendo uma tirania disfarçada de democracia; há o risco da suprema injustiça - como a que a democracia ateniense lançou sobre Sócrates, condenando-o à morte. Riscos supremos de uma experiência dinâmica do logos que não cessa de ser ameaçada pela possibilidade da própria auto-destruição. Derrida não cessa de chamar a atenção para o caráter auto-imune da democracia: "a expressão 'democracia por vir' tem em conta a historicidade absoluta e intrínseca do único sistema que acolhe em si mesmo, no seu conceito, esta fórmula de auto-imunidade a que se chama o direito à autocrítica e à perfectibilidade" (DERRIDA, 2009, 169)

\section{O Absoluto ou A Verdade com V maiúsculo}

No entanto, o risco supremo da democracia como experiência dinâmica do logos, é aquele que o próprio Platão representa: a tentação de recorrer a uma fundamentação absoluta que forneça um critério absoluto capaz de resolver e decidir com toda a segurança qualquer querela discursiva. Talvez devido ao trauma da condenação do seu mestre à morte, Platão não se conforma com a tensão insolúvel de uma série de fundamentações a cada vez relativas e dedica sua vida a estabelecer critérios absolutos capazes de fundar e legitimar absolutamente o logos. A ideia (modelo, forma, paradigma), é o fundamento absoluto, a Verdade com V maiúsculo que determina seguramente a maior ou menor correção de um dado discurso. A ideia é a razão de ser dos entes, a ideia suprema de Bem é a razão de ser do próprio mundo (PLATÃO, s/d, p. 319).

$\mathrm{Na}$ formulação de Aristóteles para a necessidade de "razões", podemos ver uma diferença capital entre filósofos atenienses e modernos: "a natureza não faz nada em vão, pois tudo o que é natural é para o benefício de algo" (ARISTÓTELES, 2010, III, $12)^{3}$. A afirmação nos deixa entrever o aspecto da causalidade que é privilegiado pela filosofia ateniense. Ser "para o benefício de algo" é a razão última de um ente, isto é, o mais importante no processo causal é a "finalidade", o que significa que, na doutrina das quatro causas, a prevalência é da causa final. Tudo o que existe, vem a ser através de uma série de comprometimentos causais tendo em vista uma finalidade superior.

A própria ideia platônica opera segundo essa lógica. Não devemos imaginar que a ideia, como uma espécie de divindade entediada e insatisfeita, produza cópias imperfeitas de si própria, nem podemos imaginar que a ideia corresponda a um modelo inicial a partir do qual, tal como numa linha de montagem, cópias são produzidas em série. A ênfase aqui não está no "produzir". A ideia de bem, como causa final, finalidade suprema de todas as coisas, que pode ser pensada como um estado maximal de ordem e perfeição, é o modelo a ser atingido pelas cópias do mundo sensível. Quando quer explicar o surgimento do mundo e das coisas do mundo, Platão recorre a uma divindade-artíficie, o demiurgo.

Ora, se o mundo é belo e o demiurgo é bom, é evidente que pôs os olhos que é eterno; se fosse ao contrário - o que nem é correto supor -, teria posto os olhos no que devém. Portanto, é evidente para todos que pôs os olhos no que é eterno, pois o mundo é a mais bela das coisas devenientes e o demiurgo 
é a mais perfeita das causas. (...) o que deveio foi fabricado pelo demiurgo que pôs os olhos no que é imutável e apreensível pela razão e pelo pensamento. (PLATÃO, 2011, p. 95)

O demiurgo é a mais perfeita das causas eficientes, mas ele ainda está submetido à perfeição da Ideia de Bem, que é a mais perfeita das causas finais:

$\mathrm{Na}$ verdade, o deus quis que todas as coisas fossem boas e que, no que estivesse à medida do seu poder, não existisse nada imperfeito. Deste modo, pegando em tudo quanto havia de visível, que não estava em repouso, mas se movia irregular e desordenadamente, da desordem tudo conduziu a uma ordem por achar que esta é sem dúvida melhor do que aquela. (PLATÃO, 2011, p. 97)

$\mathrm{O}$ demiurgo, ao criar as coisas, tem de se guiar pela finalidade suprema que é a ideia de Bem.

$\mathrm{Na}$ metafísica de Aristóteles, é ainda mais clara a prevalência da causa final. Em Aristóteles, o princípio fundamental é a substância eterna e imaterial, o Primeiro Motor, Deus (theion) ou o Bem - todos significando a mesma coisa. Posto que há movimento, que há dinamismo existencial, e que todo movimento deve ter uma causa, Aristóteles não pode conceber que se remeta um efeito dinâmico a uma causa e esta a outra causa até o infinito, fazendo necessária a introdução do Primeiro Motor - substância imaterial e eterna, causa e finalidade absoluta de todo o movimento. Mas, o primeiro motor não é também uma causa inicial que produz, tanto que é necessariamente imóvel. O primeiro motor, o theion, o Bem supremo só move enquanto finalidade suprema buscada, desejada, amada, que atrai para si as coisas e assim faz com que elas se movam: "O Bem é em todas as coisas o princípio por excelência”. E esta substância eterna, o Bem supremo, "move enquanto é amada, enquanto todas as outras coisas movem ao serem movidas” (ARISTÓTELES, 2010, XII, 7).

\section{Absolutismo racional}

No longo período predominantemente cristão, já começa a se dar a mudança que acabará por estabelecer o predomínio da causa eficiente na modernidade. Deus é supremo enquanto criador, produtor eficiente do mundo, da natureza, das coisas e dos humanos. O princípio de razão suficiente, consagrado pela fórmula de Leibniz, diz que nenhum ente pode vir a ser sem uma causa eficiente que o produza. Da mecânica newtoniana das leis e forças à linha de montagem industrial, trata-se sempre da produção de efeitos e da efetivação de produtos.

Um fundamento absolutamente seguro capaz de se dar como razão suficiente da existência, deve ser necessariamente ab-soluto e in-condicionado, isto é, livre de qualquer determinação ou condicionamento. Deve, portanto, ser necessariamente idêntico a si mesmo, dado "em si" e "por si" mesmo como presença absoluta. Aqui, o princípio de identidade e o princípio de razão se encontram, potencializando as implicações ontológicas, epistemológicas, éticas e políticas de uma visão de mundo baseada na segurança e estabilidade de um fundamento absoluto capaz de se dar como critério absoluto de distinção, classificação, fundamentação e legitimação de todo e qualquer modo de existência, discurso, bem como de toda e qualquer postura ética ou política.

O Absoluto, por ser necessariamente livre de qualquer relação, determinação e condicionamento, se coloca necessariamente para "além" do mundo, como critério absoluto capaz de decidir todo e qualquer conflito interno de posições. De acordo com o 
princípio de identidade, todo e qualquer modo de existência já será de saída enquadrado numa identidade rigidamente estabelecida e fechada para a qual todo "outro" e todo "diferente" já se dá como necessariamente "oposto". O primeiro binarismo entre "fundamento" e "fundamentado", funda e legitima uma série de oposições binárias, excludentes e hierárquicas que constituem a própria carne da visão de mundo ocidental: espírito x matéria; sujeito x objeto; bem x mal; verdade x erro/ficção/fantasia; sanidade $\mathrm{x}$ loucura; significado $\mathrm{x}$ significante; realismo $\mathrm{x}$ idealismo; natureza $\mathrm{x}$ cultura; humano $\mathrm{x}$ mundano/natural/animal; teoria $\mathrm{x}$ prática; oprimido $\mathrm{x}$ opressor; justo $\mathrm{x}$ injusto; $\mathrm{e}$ assim por diante. Nesses binarismos opositivos e excludentes, um dos polos, aquele mais próximo da "origem", mais próximo do fundamento absoluto, recebe o sinal de +, enquanto o outro é relegado a uma posição de inferioridade.

A um "outro" que não apenas é "diferente", mas "oposto" e ainda por cima "inferior", não cabe nenhum tipo de tratamento digno, de modo que a fundamentação absoluta - vigente no topo do esquema em que identidade e razão se encontram - só pode erigir um sistema de proliferação de preconceitos, no qual o outro já sempre foi pré-conceituado - e de maneira necessariamente negativa.

\section{TESTES DE REALIDADE OU "DEUS ESTÁ MORTo"}

A visão de mundo identitária, binária e centrada na razão falha em diversos "testes de realidade", mas mesmo assim mantém seu prestígio quase hegemônico, porque fornece algo que outros tipos de lógica não podem fornecer: a sensação (ainda que delirante) de segurança e estabilidade. É reconfortante dispor de um poder absoluto de fundamentação ontológica, epistemológica e ético-política. É reconfortante saber onde está cada coisa, onde começam e onde terminam as fronteiras. É reconfortante dispor de uma definição precisa para cada coisa, pessoa, valor e instituição. É reconfortante dispor de critérios epistemológicos e éticos absolutamente válidos. Mas é tudo tão ilusório que quando começamos a nos dar conta da farsa em que estamos metidos, o esquema "absolutista" ocidental deixa de ser reconfortante e se torna progressivamente incômodo e limitante.

É claro que o desenvolvimento de tais ferramentas lógicas deve ter sido fundamental para uma época em que tudo dependia do discurso. Como deixar a vida da polis ao cargo de discursos que afirmam que um cavalo é um deus, que uma oliveira é uma deusa, que o vôo de uma águia é também um presságio bom ou ruim, que definem valores e virtudes com base nas mais particulares idiossincrasias? Nos colocando tão criticamente em relação a estes dois princípios lógicos fundamentais, agimos de certa forma com ingratidão, tal como Platão ao criticar a democracia e suas instituições sendo que ao menos existiam instituições! É a provocação de Protágoras a um Sócrates descontente:

De igual modo, você acredita, agora, que o homem que lhe parece o mais injusto, dentre todos os que foram criados nas leis e entre os homens, é, no entanto, justo e hábil se o comparamos a homens que não têm nem educação, nem tribunais, nem leis, nem outra qualquer coação que os force a se ocuparem, constantemente, da excelência. (...) Certamente, se você se encontrasse entre tais homens (...) certamente se felicitaria ao deparar-se com um Euríbato ou com um Frinondas, e se lamentaria, com saudade, da maldade dos homens daqui! Agora, você age com desdém, caro Sócrates, porque todos, cada qual na medida dos seus próprios meios, são professores de excelência, embora ninguém, a seus olhos, se encontre em condições de ensiná-la. (ap. CASSIN, p. 345) 
De fato! Platão em Atenas é um crítico, um "intelectual” avant-la-lettre. Platão em Siracusa é sumariamente preso e escravizado! No entanto, por mais importantes que sejam os princípios lógicos, uma vez que eles se hipostasiam e passam a configurar toda uma "visão de mundo" repleta de graves implicações ético-políticas, tornam-se eles próprios o "sintoma" a ser analisado.

A lógica identitária e o absolutismo racional ignoram a sabedoria pré-socrática: se as coisas se afetam umas às outras de múltiplas maneiras, elas não podem ser "algo" "em si", dado "por si" mesmo, nem podem estar completamente encerradas nos limites das fronteiras intransponíveis de uma identidade fechada. Se as coisas se afetam umas às outras de múltiplas maneiras é necessário que elas tenham algo em comum. Do contrário elas seriam absolutamente in-comun-icáveis. Algo que existisse "em si" e "por si" mesmo, livre de qualquer relação, limitação, determinação e condicionamento, seria uma presença eternamente vigente no "além", isto é, para além de qualquer relação mundana. Mas de onde poderia ter vindo um tal ente? E se de fato existisse, como poderíamos falar sobre ele, conhecê-lo, afetá-lo e ser por ele afetados? Não haveria qualquer possibilidade. Um ente "em-si" estaria para sempre condenado ao isolamento puro e à mais incontornável incomunicabilidade.

Quando paramos para realmente analisar os binarismos da razão ocidental, vemos que há certa comunicabilidade entre eles: um remédio "material" é capaz de intervir numa perturbação "espiritual", uma simples conversa, um gesto, um olhar carregados de sentido, podem intervir instantaneamente sintomas "físicos" como uma dor de cabeça ou uma dor no peito. Quando a indústria devasta os recursos naturais do planeta, a cultura interfere na natureza. Quando o aquecimento global toma conta dos debates políticos, a natureza interfere na cultura. Quando "eu" preciso de ar, água, luz, alimentos, linguagem, interações sociais e determinações culturais para "ser o que sou", onde fica a fronteira entre "eu" e o "mundo"? Quando as peripécias dos "caçadores de pokémon" que se aventuram pelas ruas das grandes cidades interferem no "mundo real", onde fica a fronteira entre "realidade" e "ficção"? Quando "os bons" julgam e condenam, perseguem, excluem e agridem "os maus", onde fica a fronteira entre "bem" e "mal"? Se há interferências, relações, afetações, con-fusões, quer dizer que as fronteiras não são assim tão rígidas, que há pontos de passagem e pontos de indistinção. E se há tudo isso, tem de haver uma "nota comum" (MAGNO, 2007, p. 119) que torne possível a relação e a comunicabilidade entre os supostos "polos".

E se há comunicabilidade, afetação mútua e relação, então não há nenhum Absoluto, pois Absoluto é, por definição, aquilo que é livre de toda e qualquer relação, limitação, determinação e condicionamento. E se não há nenhum absoluto - um dos mais profundos significados da polêmica frase de Nietzsche "Deus está morto" (NIETZSCHE, GC, § 125) - então tudo tem que ser repensado. Todas as nossas certezas estão novamente sob suspeita e novos caminhos de investigação precisam ser construídos. Se não há nenhum absoluto, então precisamos repensar e reconstruir ontologias, epistemologias, éticas, políticas e estéticas. Como funciona um mundo sem o Absoluto? Exercício arriscado, raro e singular que terá contra si, em todos os tempos, a opinião estabelecida.

\section{A RE(D)ALIDADE}

Para voltar aos nossos princípios (onto)lógicos, como funcionariam as "identidades" e as "razões" sem a presença do absoluto? Ora, se não há absolutos, tudo é relacional, tudo vem a ser a partir de uma relacionalidade geral, tudo sempre já vem a 
ser numa rede complexa de relações. Mas, se tudo é relacional, nos vemos novamente diante da aporia que deu origem ao pensamento filosófico com os pré-socráticos: se só há relações, é preciso que haja um princípio comum, uma mesmidade radical que, atravessando e permeando todas as coisas, seja a garantia de sua comunicabilidade. Por outro lado, para haver relação, é preciso que haja também diferença, ou todas as coisas seriam de saída a mesma e não haveria qualquer relação. Como pensar a mesmidade na multiplicidade, a mesmidade na diferença, sem novamente recorrer ao absoluto, ao identitário e ao binário? Desafio dos desafios para um pensamento que se recusa o conforto e a preguiça do "absolutismo" racional.

Desafio ao qual Schopenhauer e Nietzsche, (aos quais a tradição maldosamente conferiu o rótulo de "irracionalistas", medindo-os por um parâmetro que não é o deles ou seja, o parâmetro do racionalismo) responderam com um "terceiro" historicamente "excluído" pela tradição: a "vontade" e a "vontade de poder", isto é, a dimensão pulsional (BOGÉA, 2016). A dimensão pulsional não é nem material nem espiritual, nem física nem mental, é além de "realidade" e "ficção", é "além de bem e de mal". A mesma pulsão anima todos os entes existentes, mas esse "mesmo" é um impulso egoístico de proliferação de diferenças, de afirmação intransigente da singularidade de cada configuração de circunstâncias.

Se tudo é relacional, toda "identidade" é atravessada e constituída por alteridades e diferenças múltiplas. "Eu" não consigo "me apresentar", dizer "quem sou", sem recorrer a uma série de "outros" que me atravessam e me constituem: nome, profissão, relações de parentesco, valores sócio-culturais, posicionamentos políticos, tudo através da mediação de uma linguagem, de reações fisiológicas que me mantém "funcionando" etc. Por isso Derrida, numa negação decidida da "presença identitária", afirma que só há diferenças e que o próprio de toda suposta identidade "é ser diferente de si mesma" (DERRIDA, 1995, p. 96). Parte-se já da diferença, do diferente, do diferente de si e do diferente a si. Há différance, impetuoso processo de produção e proliferação de diferenças, sem possibilidade de um reconfortante encontro ou reencontro consigo mesmo, perfeita identificação a si, retorno a si próprio, reapropriação de si. É a diferença pensada da maneira mais radical: na raiz, está a diferença, que por só poder ser diferente a si, afirma em si o que lhe é outro, e não a identidade que por ser si mesma é diferente das outras em si. (DERRIDA, 2004)

Se tudo é relacional, não há nenhuma "razão última" de ser para as coisas e é preciso acompanhar, em cada caso, a rede de relações em tensão que provisoriamente legitimam e sustentam uma determinada configuração circunstancial. Uma rede de circunstâncias múltiplas e diversas, entrelaçadas, agindo e reagindo umas sobre as outras, vão fazendo emergir em seu jogo conflituoso-harmonioso, várias configurações circunstanciais que se estabilizam provisoriamente como "objetos", "pessoas", "valores", “instituições", “domínios sócio culturais" etc. É mais ou menos esse o sentido da "teoria do ator-rede" de Bruno Latour: o protagonismo da "agência" não cabe ao humano, não se trata em cada caso de um humano racional e consciente que planeja e executa realizando "feitos" científicos, históricos, culturais etc. Há uma "rede" de "atores" heterogêneos que, numa conjunção complexa de afetações e atravessamentos configuram "ciência", "história", "cultura", etc. Se alguém se propõe a investigar "A Ciência" em sua pureza e para tal entra em seu terreno próprio, o laboratório:

ali encontra pessoas de jaleco branco, provetas de vidro, cultivos de micróbios, artigos com notas de pé de página: tudo indica que se encontra "no terreno da Ciência"; logo se põe a anotar com obstinação de onde provém os 
ingredientes sucessivos que seus informantes necessitam para levar adiante seu trabalho. Ao proceder desta maneira, a jovem reconstitui muito rapidamente uma lista de ingredientes que se caracterizam (...) por conter elementos cada vez mais heterogêneos. No mesmo dia pode ter anotado a visita de um jurista que foi tratar das questões de patentes, um pastor para as questões de ética, um técnico para a reparação de um novo microscópio, de um escolhido para o voto de uma subvenção, de um business angel para o lançamento da próxima start-up, de um industrial para ajustar um novo fermentador, etc. Uma vez que seus informantes asseguram que todos esses atores são necessários para o êxito do laboratório, ao invés de identificar os limites de um domínio, sempre questionados por diversas manchas, nada lhe impede de seguir as conexões de um elemento, pouco importa qual, e ver aonde leva. (LATOUR, 2013, p. 44)

Portanto, elementos heterogêneos tais como objetos materiais de todo tipo; micróbios; valores éticos; valores religiosos; auxílios econômicos; meios de propaganda e divulgação; questões jurídicas; e interesses políticos são efetivamente atuantes na dinâmica do laboratório. São "atores" que, em rede, constroem "resultados", "descobertas", "cientistas" e, de certa forma, aquilo mesmo que se pode chamar de "ciência". E, curiosamente, nenhum destes "atores" é algo "em si", nem uma "presença" ou "identidade" previamente dadas. Cada um deles é igualmente desdobrável numa rede de "atores" num processo interminável, mas a cada vez interrompido pelas próprias limitações intrínsecas à linguagem.

\section{METAFÍSICA DO IMPOSSÍVEL: ENTRE A ESTUPIDEZ E A LOUCURA}

Fernando Pessoa (1986, p. 155) descreveu com muita precisão nossa situação existencial nos seguintes versos:

Só quem puder obter a estupidez

Ou a loucura pode ser feliz.

Buscar, querer, amar... tudo isto diz

Perder, chorar, sofrer, vez após vez.

A estupidez achou sempre o que quis

Do círculo banal - da sua avidez;

Nunca aos loucos o engano se desfez

Com quem um falso mundo seu condiz.

Há dois males: verdade e aspiração,

E há uma forma só de os saber males:

É conhecê-los bem, saber que são

Um o horror real, o outro o vazio -

Horror não menos - dois como que vales

Duma montanha que ninguém subiu.

Buscar, querer, amar... condição original de um mundo pulsional, condição nem ainda louca, nem ainda estúpida, mas potencialmente louca e estúpida. Pulsão nada mais é que isso: buscar, querer, amar... Toda a interminável inquietação do mundo: na 
violência primitiva da cadeia alimentar; na disputa febril por energia e por espaço que envolve bactérias, protozoários, insetos, vegetais, répteis, aves, mamíferos; na eterna luta humana por domínio, por status, por honra, por prestígio, por bens materiais; no movimento repetitivo dos astros siderais, sustentado pela implacável força da gravidade; Por toda parte há busca, querer, amor, numa palavra: pulsão.

Mas, buscar, querer, amar não pode não ser perder, chorar, sofrer, "vez após vez". Pois a inquietação pulsional não tem fim. Se tivesse fim seria a morte, o nada, "menos que nada", o próprio não-Haver, que não há. Querer é querer o impossível. E todos nós sabemos, se não conceitualmente, mas certamente sabemos na pele, na carne e nas entranhas o que isso significa. Cada desejo não realizado nos atira no mais inconsolável sofrimento e o sofrimento, a cada vez que toma o poder, como sabemos, é soberano. Mas a satisfação também tem suas "vicissitudes". Cada desejo satisfeito deixa um gosto de "ainda não era isso...", mas mesmo quando a ilusão da completude é tão perfeita que nos faz dizer "sim! É isso!", as "placas tectônicas" das configurações circunstanciais se movimentam novamente e nos levam embora a sensação de plenitude satisfeita. Por mais que tentemos resistir, o esforço, o investimento, o custo para manter uma dada situação circunstancial são tão altos, que nos exaurem as energias, de maneira que quando percebemos, a própria situação que tanto nos esforçamos para preservar, tornou-se uma prisão e uma fonte de desgosto e sofrimento. Mas, por outro lado, se as "placas tectônicas" se mostram estáveis o bastante, logo começam a nos parecer "estáveis demais..." e a alegre satisfação vai se tornando cada vez mais uma lembrança para dar lugar ao tédio que se instala pouco a pouco até que nos domina por completo. É o pêndulo schopenhaueriano que não cessa de oscilar do sofrimento para o aborrecimento.

O mundo das identidades e das razões absolutas é, de uma certa forma, um mundo da "estupidez", um mundo que já desde o princípio, "achou sempre o que quis". Achou desde o princípio a plenitude satisfeita de uma autoidentidade plenamente constituída. Achou desde o princípio a plenitude satisfeita, a segurança e a estabilidade absolutas, a suposta realização plena e total que o Absoluto promete. E, no entanto, a ânsia (in)consciente de romper de uma vez com o estabelecido, o instituído, com a "camisa de força" sociocultural pode engendrar o "engano", o delírio, a alucinação com os quais um "falso mundo" condiz. E isso não é ainda a loucura, pois mundo é isso e isso é o que há. A loucura é que esse engano nunca se desfaça. A loucura é que se acredite nesse "engano" e nesse "falso mundo".

Vivendo na re(d)alidade, isto é, na realidade que um mundo em rede engendra, vivemos na corda bamba entre a estupidez e a loucura. "No sentido de Fernando Pessoa: há duas maneiras de sobrevivermos, a estupidez ou a loucura" (MAGNO, 2007, p. 89). Se respeitarmos demais as circunstâncias estabelecidas, é a estupidez. Se não respeitarmos nem um pouco a circunstâncias estabelecidas, se acharmos que estamos em condições de simplesmente nos lançar "para além" delas, é a loucura. É preciso estar em permanente negociação com as circunstâncias. Uma negociação "interminável", como a "análise", segundo Freud (FREUD, 1996). Se, por respeito excessivo às circunstâncias, deixamos de negociar, acreditamos que as circunstâncias sejam A Realidade, com R maiúsculo, a própria verdade absoluta e imutável das coisas. A vida no interior dessas fronteiras rígidas - ou mesmo intransponíveis - torna-se insuportavelmente limitada, engessada, "estúpida". No entanto - não nos enganemos quanto a isso - as circunstâncias, isto é, as coisas, as pessoas, as instituições, as identidades, os absolutos, os deuses... têm poder. Eles estão investidos de poder pela determinada situação circunstancial da rede que os constitui. E porque eles têm poder, $e ́$ preciso negociar com eles a cada passo. 
O Estado pode ser apenas o efeito de uma "comunidade imaginada" (ANDERSON, 2008), suas leis apenas "frases escritas num papel”, mas se você insistir em desobedecer as leis do Estado, o "braço armado" do Estado vai agir de fato e você vai efetivamente sofrer as consequências. Os deuses podem ser fantasias, mas se você não souber negociar com eles, seus seguidores vão realmente te perseguir, te excluir e te violentar - seja te jogando na fogueira, te "aterrorizando" com bombas e fuzis, ou censurando e criminalizando sua liberdade de expressão. A "matéria", as circunstâncias "físicas", "biológicas" e "químicas" podem ser apenas dados construídos por certos modelos descritivos, simbólicos, inexatos e até certo ponto delirantes. Mas, se você não souber negociar com eles, eles vão te impor graves limitações e podem mesmo te destruir. Se você não tiver estratégias mínimas para "cuidar do corpo", com intervenções físicas, químicas e biológicas, ele vai falir. Se você não souber fazer a leitura correta dos "objetos materiais" que o rodeiam, sua "qualidade de vida" ficará gravemente prejudicada.

Não adianta "ir além" das circunstâncias e se esquecer de negociar com elas, porque elas vão cobrar o preço. Existir é uma "metafísica do impossível": nem temos fundamentos absolutamente seguros sobre os quais repousar, nem deixamos de, em meio ao frenético movimento das circunstâncias, desejar e fantasiar alguma possibilidade de fundamentação. Lucidez é a negociação interminável que se sabe negociação, ou seja, é cuidar para não tratar nem com "a realidade" pura nem com a "pura ficção", nem com o puro fundamento, nem com o puro nada. É habitar o entreato, o intermédio, o espaço "indecidível” (DERRIDA, 2001, p. 49) 4 entre realidade e ficção, isto é, tratando com "realidades fictícias" e "ficções reais". Não é uma tarefa fácil, nem uma "ciência exata". É uma negociação, e, como tal, envolve apostas, investimentos, estratégias, avanços e recuos, perdas e ganhos. É um desafio, o desafio de uma vida. Vivida numa corda bamba estendida entre dois abismos, entre dois "vales": a estupidez e a loucura.

\section{REFERÊNCIAS BIBLIOGRÁFICAS}

ANDERSON, Benedict. Comunidades imaginadas: reflexões sobre a origem e a difusão do nacionalismo. Trad. Denise Bottman. São Paulo: Companhia das Letras, 2008

ARISTÓTELES. De Anima (Sobre a Alma). Rio de Janeiro: Imprensa Nacional Casa da Moeda, 2010

. Metafísica. São Paulo: Loyola, 2002

BOGÉA, D. Metafisica da vontade, metafísica do impossível: a dimensão pulsional como terceiro excluido. Tese de Doutorado. PUC-Rio, 2016

BORNHEIM, Gerd. Os filósofos pré-socráticos. São Paulo: Cultrix, 1998

CASSIN, B. O efeito sofístico. São Paulo: 34, 2005

DERRIDA, J. Gramatologia. São Paulo: Perspectiva, 2004.

Posições. Belo Horizonte: Autêntica, 2001

Vadios: dois ensaios sobre a razão. Coimbra-PT: Palimagem, 2009

O outro cabo. Tradução F. Bernardo. Coimbra: A Mar Arte, 1995

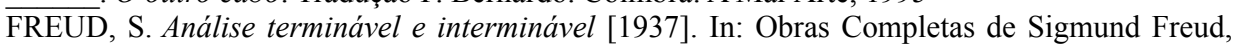
Vol. XXIII. Rio de Janeiro: Imago Ed., 1996

HEIDEGGER, M. A questão da técnica in Ensaios e Conferências. Petrópolis: Vozes, 2012, pp. $11-38$

HERÁCLITO. Os pré-socráticos (Coleção Os Pensadores). São Paulo: Abril, 2000

KANT, I. Crítica da Razão Pura (Coleção Os Pensadores). Trad: Valério Rohden. São Paulo: Abril Cultural, 1974

LATOUR, Bruno. Investigación sobre los modos de existencia. Buenos Aires: Paidós, 2013, p. 
44

LEIBNIZ, Monadologie (1714), Librarie Delgrave, Paris, 1966

Clavis Universalis: da cura em psicanálise ou revisão da clínica. Rio de Janeiro: Novamente, 2007

NIETZSCHE, Friedrich. Humano, demasiado humano. São Paulo: Cia das Letras, 2005 (HH) . A Genealogia da Moral. São Paulo: Cia Das Letras, 2009 (GM) . A Gaia Ciência. São Paulo: Cia das Letras, 2001 (GC)

PESSOA, F. Obra Poética e em Prosa. Vol. I. (Introdução, organização, biobibliografia e notas de António Quadros e Dalila Pereira da Costa.) Porto: Lello, 1986.

PLATÃO. Timeu-Crítias. Tradução: Rodolfo Lopes. Coimbra: CECH, 2011 . A República. Tradução: Maria Helena da Rocha Pereira. Lisboa: Fundação Calouste Gulbenkian, s/d

PROTÁGORAS. Fragmentos. In: PEREIRA, Maria Helena da Rocha. Hélade: antologia da cultura grega. Coimbra: FLUC, 1982

\section{Notas}

$1 \mathrm{Na}$ segunda dissertação de A Genealogia da moral, Nietzsche faz as noções "espirituais" de "culpa" e "responsabilidade" remontarem às noção bastante "material" de "dívida". (Nietzsche, GM, II)

$2 \mathrm{O}$ princípio de isegoria garantia a todos os cidadãos o igual direito à palavra.

3 ARISTÓTELES, De Anima, 3.12, 434a31-32

4 "Indecidível" é uma formulação de Derrida para tratar dessas zonas indetermináveis de indiferenciação: indecidíveis são "unidades de simulacro, falsas propriedades verbais, nominais ou semânticas, que não mais se deixam compreender na oposição filosófica (binária) e que, no entanto, habitam-na, resistem-lhe, desorganizam-na, mas sem jamais constituir um terceiro termo, sem jamais engendrar uma solução na forma da dialética especulativa (...) nem/nem é ao mesmo tempo ou isso ou aquilo". DERRIDA, Posições, p. 49 